\title{
SEHAT DIMASA PANDEMI COVID 19
}

\author{
Viki Yusri'1, Febriyanti², Vivi Syofia Sapardi ${ }^{3}$, Armein Syahid ${ }^{4}$, Civany Bettania \\ Putri $^{5}$, Belinda Efrin ${ }^{6}$, Jelita Anriani Siregar ${ }^{7}$ \\ 1234567Prodi DIII Keperawatan STIKes MERCUBAKTIJAYA Padang \\ E-mail korespondensi: viyuviyu80@gmail.com
}

\begin{tabular}{l}
\hline Article History: \\
Received: $29-11-2021$ \\
Revised: $3-12-2021$ \\
Accepted: 20-12-2021 \\
\\
Kata Kunci : Hidup Sehat, \\
Pandemi Covid-19, Virus
\end{tabular}

Keywords: Healthy Living, Covid-19 Pandemic, Virus

\begin{abstract}
Abstrak:
Latar Belakang: Pandemi COVID 19 memang membawa berbagai perubahan dalam hidup manusia. Pola hidup sehat dan bersih sebenarnya sudah diimbau sejak lama, namun kebiasaan ini baru benar - benar diterapkan sejak pandemi COVID-19 terjadi. Berdasarkan data PNBP mencatat bahwa Kota Padang berada pada Zona Merah yang memang harus di perhatikan. Oleh karena itu di Era New Normal ini Sekolah dihimbau untuk dapat menerapkan pola hidup sehat dan bersih serta mengkonsumsi herbal imuniti untuk kekebalan tubuh agar terhindar dari serangan virus COVID19. Tujuan pengabdian masyarakat ini adalah meningkatkan pengetahuan warga dan membangun kesadaran warga terhadap kebersihan dan kesehatan lingkungan.
\end{abstract}

Metode: Metode pendekatan yang diterapkan dalam kegiatan ini meliputi metode ceramah, serta metode diskusi Kegiatan pengabdian ini telah dilaksanakan pada hari Minggu tanggal 9 Mei 2021 di Mesjid Nurul Falah Linggar Jati Kelurahan Parupuk Tabing Kota Padang. Sasaran pengabdian ini adalah remaja dan masyarakat.

Hasil: 90\% dari 85 orang peserta antusias mendengar topik yang diberikan, dan $45 \%$ peserta merespon dalam materi yang diberikan serta $60 \%$ peserta paham apa yang harus dilakukan untuk kedepannya. Waktu pelaksanaan dilaksanakan mulai pukul 07.00 sampai dengan 11.00 WIB.

\section{Abstract:}

Background: The COVID-19 pandemic has brought about various changes in human life. A healthy and clean lifestyle has actually been advocated for a long time, but this habit has only really been implemented since the COVID-19 pandemic occurred. Based on PNBP data, it is noted that The city of Padang is in the Red Zone which must be considered. Therefore, in this New Normal Era, schools are encouraged to be able to apply a healthy and clean lifestyle and consume immunity herbs to avoid the COVID-19 virus attack. The purpose of this community service is to increase the knowledge of citizens and build awareness of the community towards environmental hygiene and health.

Method : Approach methods applied in this activity include a lecture method, and discussion method. This service activity was carried out on Sunday, May 9, 2021 at the Nurul Falah Linggar Jati Mosque, Parupuk Tabing Village, Padang City. The target of this service is youth and society. 


\section{Jurnal ABDI MERCUSUAR}

Vol. 01, No. 02, Desember, 2021, pp. 059 - 066

Result: $90 \%$ of the 85 participants enthusiastically heard the topic given, and $45 \%$ of the participants responded in the material provided and $60 \%$ of the participants understood what to do in the future. The implementation time is from 07.00 to $11.00 \mathrm{WIB}$

\section{Pendahuluan}

Perilaku Hidup Bersih dan Sehat (PHBS) disekolah adalah sekumpulan perilaku yang dipraktikkan oleh peserta didik, guru, dan masyarakat lingkungan sekolah atas dasar kesadaran sebagai hasil pembelajaran, sehingga secara mandiri mampu mencegah penyakit, meningkatkan kesehatannya, serta berperan aktif dalam mewujudkan lingkungan sehat. Ada beberapa indikator yang dipakai sebagai ukuran untuk menilai PHBS di sekolah yaitu: 1) mencuci tangan dengan air yang mengalir dan menggunakan sabun; 2) mengkonsumsi jajanan sehat di kantin sekolah; 3) menggunakan jamban yang bersih dan sehat; 4) olahraga yang teratur dan terukur; 5) Memberantas jentik nyamuk; 6) tidak merokok di sekolah; 7) menimbang berat badan dan mengukur tinggi badan setiap 6 bulan; 8) membuang sampah pada tempatnya. Lingkungan yang bersih dan sehat adalah lingkungan yang bebas dari berbagai kotoran, termasuk diantaranya debu, sampah dan bau. Lingkungan yang bersih dan sehat berarti harus bebas dari virus, bakteri dan berbagai vektor penyakit serta bebas dari bahan kimia berbahaya termasuk virus corona atau COVID-19 (Pratiwi Eka, 2015).

Penyebaran Virus COVID-19 sangat cepat dan hampir seluruh negara terpapar dengan virus ini. Virus ini diketehui awal mulanya tersebar di negeri Cina tepatnya di Wuhan. Tidak bisa dipungkiri bahwa kasus penyebaran COVID-19 ini juga menjangkit di negara Indonesia dan hampir seluruh provinsi terjangkit termasuk Sulawesi selatan. (Idah Wahidah, Muhammad Andi Septiadi, M. Choerul Adlie Rafqie, Nur Fitria, Salsabila Hartono, 2020) dalam tulisanya menjelaskan bahwa pada tanggal 13 April 2020 tercatat diIndonesia ada 4.557 kasus positif dan juga dilaporkan 380 orang sembuh serta 399 orang dinyatakan meninggal karena COVID-19. Dari kejadian ini banyak sekali cara yang ditempuh oleh pemerintah agar dapat meminimalisir tingkat penularan dari penyebaran COVID-19 ini, diantaranya memberlakukan Rapid Test atau test cepat untuk mengetahui orang yang terdeteksi oleh COVID-19, hingga Physical Distancing dan bahkan Lockdown. Namun selain cara seperti diatas untuk meminimalisir penyebaran COVID-19, PHBS kepada seseorang, keluarga atau sekelompok masyarakat agar dapat menolong diri mereka sendiri dibidang kesehatan dan berperan aktif dalam mewujudkan kesehatan masyarakat. Diantara PHBS ini yang perlu dilakukan dalam masa pandemi ini diantaranya, cara melakukan Physical Distancing (jaga jarak), cara menerapkan etika batuk dan cara mencuci tangan yang baik dan benar.

Dalam PHBS juga dilakukan edukasi untuk meningkatkan pengetahuan, sikap dan perilaku melalui pendekatan pimpinan (advocacy), bina suasana (social support) dan hpemberdayaan masyarakat (empowerment) (Luthviatin., 2012). Perilaku Hidup Bersih dan Sehat yang harus dilakukan oleh setiap individu/keluarga/kelompok sangat banyak, dimulai dari bangun tidur sampai dengan tidur kembali. Perilaku Hidup Bersih 


\section{Jurnal ABDI MERCUSUAR}

Vol. 01, No. 02, Desember, 2021, pp. 059 - 066

dan Sehat adalah sekumpulan perilaku yang dipraktekkan atas dasar kesadaran sebagai hasil pembelajaran yang menjadikan individu / keluarga / kelompok dapat menolong dirinya sendiri dalam bidang kesehatan dan berperan aktif dalam mewujudkan derajat kesehatan masyarakat. Seperti kita ketahui bahwa Indonesia saat ini sedang mengalami Pandemic COVID-19. COVID-19 merupakan suatu penyakit menular yang disebabkan oleh coronavirus yang baru ditemukan. Virus ini mulai mewabah di Wuhan, Tiongkok sejak bulan Desember 2019. Dengan penyebaran yang sangat cepat, sehingga hingga saat ini COVID-19 telah menjadi sebuah pandemi yang terjadi di seluruh dunia. COVID19 ini memberikan pengaruh yang sangat besar terhadap segala aspek kehidupan, dan segala bidang yang ada di suatu negara. Indonesia menjadi salah satunya negara yang terdampak COVID-19. Pola Hidup Bersih dan Sehat di Era New Normal ini harus di terapkan dengan sebaik mungkin oleh masyarakat. Berdasarkan data yang bersumber dari BNPB Indonesia sampai saat ini tanggal 09 Mei 2021 jumlah warga negara Indonesia yang terpapar Virus Corona mencapai 3.922 Kasus perhari, dan Sumbar mencapai 323 Kasus perhari dan total kasus positif 39.166 kasus (UNICEF, 2020).

Pandemic COVID-19 memang membawa berbagai perubahan dalam hidup manusia. Mulai dari aktivitas seperti bekerja maupun kegiatan belajar yang dilakukan di rumah, sejumlah rencana yang akhirnya harus dibatalkan, hingga perubahan pola dan gaya hidup dengan lebih memprioritaskan kesehatan. Pola hidup sehat dan bersih sebenarnya sudah diimbau sejak lama, namun kebiasaan ini baru benar- benar diterapkan sejak pandemi COVID-19 terjadi. Berdasarkan data PNBP mencatat bahwa Kota Padang berada pada Zona Merah yang memang harus di perhatikan. Oleh karena itu di Era New Normal ini Sekolah dihimbau untuk dapat menerapkan pola hidup sehat dan bersih serta mengkonsumsi herbal imuniti untuk kekebalan tubuh agar terhindar dari serangan virus COVID-19 (Budianto, 2020).

Dari survey awal didapatkan analisis stuasi mitra berada di tengah kota Padang yang dimana penduduknya banyak yeng remaja dan masa produktif dimana tingkat mobilitasnya sangat tinggi yang akan berdampak resiko tinggi dalam penularan penyakit corona virus yang sedang melonjak angka kejadinaya saat ini, dan diketahui permasalahan mitra yang seang dihadapi diantaranya adalah masih banyaknya masyarakat disekitar tidak patuh atau taat dalam dalam menghindari atau mencegah COVID-19 seperti jarang pakai masker dan tidak mau selalu cuci tangan seperi yang dianjurkan WHO.

Tujuan dari kegiatan pengabdian kepada masyarakat ini adalah (1) untuk membangun kesadaran warga terutama para remaja terhadap kebersihan dan kesehatan lingkungan, (2) meningkatkan pengetahuan warga di lingkungan sekolah dalam pengelolaan lingkungan, dan (3) meningkatkan partisipasi warga sekolah dalam hal kebersihan dan kesehatan lingkungan sehingga tercipta perilaku hidup dan lingkungan yang bersih, asri, nyaman, dan sehat yang dapat meningkatkan proses belajar mengajar. Mitra kerjasama kegiatan ini adalah remaja di Mesjid Nurul Falah Linggar Jati Kelurahan Parupuk Tabing Kota padang. Metode pelaksanaan pengabdian kepada masyarakat terdiri dari tiga tahap yaitu persiapan, pelaksanaan dan 
evaluasi.

\section{Metode Pelaksanaan}

Pelaksanaan pengabdian masyarakat dilakukan di Mesjid Nurul Falah Linggar Jati Kelurahan Parupuk Tabing Kota Padang. Strategi atau metode pendekatan yang diterapkan dalam kegiatan ini meliputi pendekatan partisipatif, pendekatan kelompok, pendekatan individual, metode ceramah, metode diskusi/FGD. Pendekatan partisipatif digunakan agar masyarakat ikut berpartisipasi secara aktif terhadap semua kegiatan mulai dari awal sampai akhir. Pendekatan kelompok digunakan untuk melaksanakan pendidikan kesehatan.

Metode yang akan dilakukan pada kegiatan pengabdian adalah Strategi Pelaksanaan supaya dapat mencapai target luaran yang telah ditetapkan, maka tim pengabdi merencanakan rancangan pelaksanaan kegiatan ini dilakukan dengan melakukan pendekatan partisipatif dan kelompok, agar pihak remaja dan masyarakat di Mesjid Nurul Falah Linggar Jati Kelurahan Parupuk Tabing Kota Padang berpartispasi aktif terhadap kegiatan ini dari awal hingga akhir. Kegiatannya sebagai berikut : Perencanaan terdiri dari (1) Melakukan survey awal terkait permasalah yang terjadi pada mitra, (2) Koordinasi dengan penanggung jawab Mesjid Nurul Falah Linggar Jati, (3) Mempersiapkan fasilitas dan saran untuk kelengkapan pengabdian masyarakat. b) Tindakan Memberikan edukasi pada masyarakat tentang sehat dimasa pandemi. Pemberian materi adalah narasumber dari Tim pengabdi sendiri, dalam hal ini melibatkan mahasiswa sebagai fasilitator yang akan membantu melancarkan kegiatan ini.

\section{Hasil}

Penyelenggaraan pengabdian kepada masyarakat ini dilaksanakan berdasarkan analisa situasi dan permasalahan mitra. Kegiatan pengabdian masyarakat dilaksanakan pada hari Minggu tanggal 9 Mei 2021. Peserta berjumlah 85 orang yang terdiri dari remaja dan masyarakat di Mesjid Nurul Falah Linggar Jati Kelurahan Parupuk Tabing Kota padang. Waktu pelaksanaan dimulai pukul 07.00 sampai dengan 11.00 WIB. Materi tentang sehat dimasa pandemi COVID-19 diberikan oleh Tim Pengabdi dari STIKes MERCUBAKTIJAYA Padang dengan hasil yang didapatkan 90\% dari 85 orang peserta antusias mendengar topik yang diberikan, dan $45 \%$ peserta merespon dalam materi yang diberikan serta $60 \%$ peserta paham apa yang harus dilakukan untuk kedepan nya. 


\section{Jurnal ABDI MERCUSUAR}

Berikut adalah dokumentasi pelaksanaan kegiatan pengabdian masyarakat.

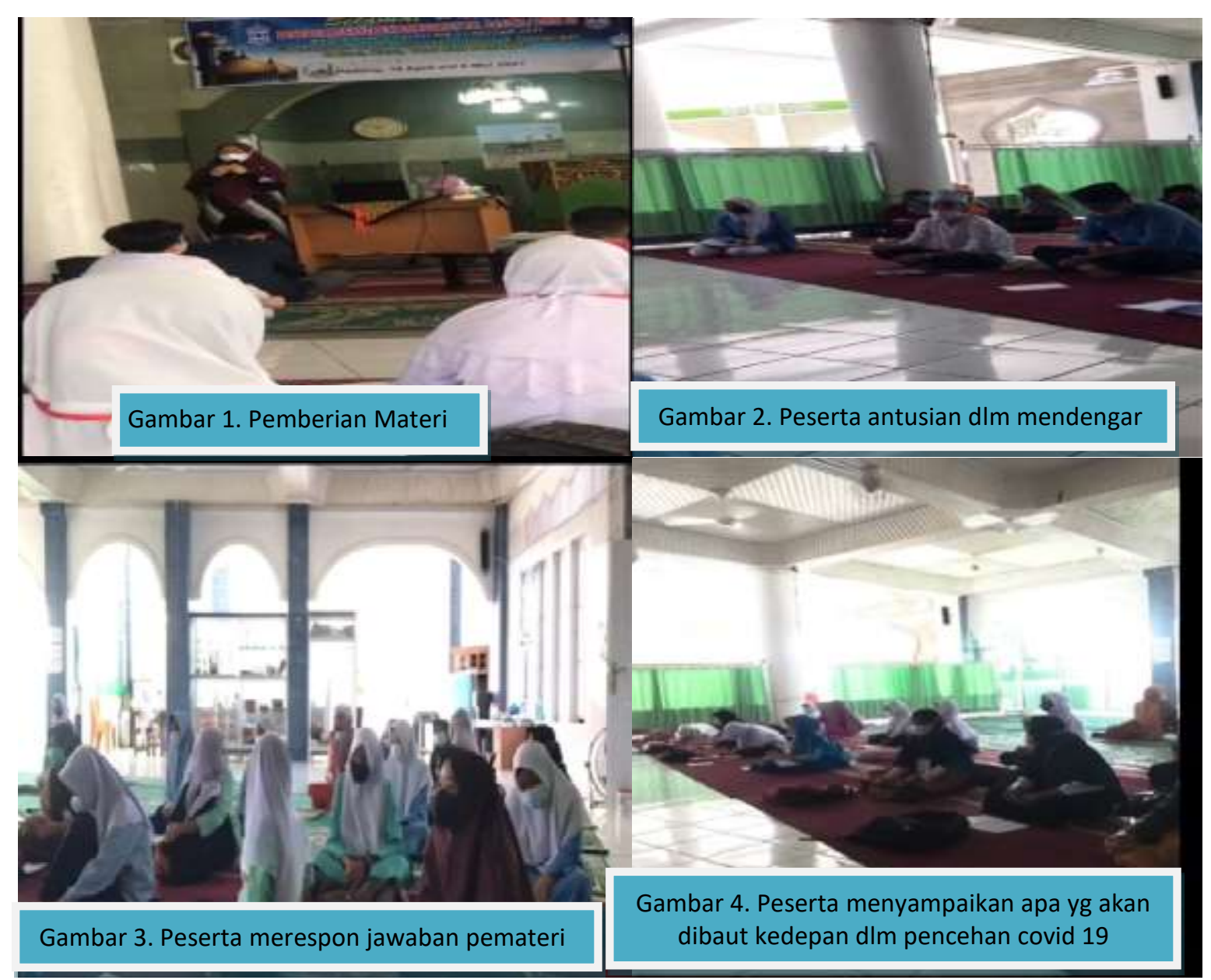

Gambar 1. Pemaparan Materi tentang sehat dimasa pandemi COVID-19

\section{Diskusi}

Meningkatnya penderita yang terinfeksi virus COVID-19 di Indonesia maupun di dunia, sangat dipengaruhi oleh pola hidup bersih dan sehat masyarakat. Apabila pola hidup bersih dan sehat ini dapat terlaksana dengan baik, maka seseorang dapat meminimalisir terhindar dari virus. Melaksanakan perilaku hidup bersih dan sehat baik sebelum maupun selama pandemi COVID-19 yakni dengan tetap berolahraga dan menjaga pola hidup sehat dan bersih. Jenis olahraga yang banyak dilakukan selama masa pandemi COVID-19 dengan melakukan senam, jogging dan bersepeda. Sedangkan untuk aktivitas fisik di rumah dengan lebih banyak melakukan kegiatan seperti membersihkan rumah dan memasak. Dengan menerapkan pola hidup bersih dan sehat serta rutin berolahraga rata-rata minimal 30 menit perhari maka tingkat percaya diri kita akan tubuh dengan bugar sehat karena berolahraga akan terhindar dari pandemi COVID-19 (Kementerian Kesehatan Republik, 2020b).

Berbagai upaya telah dilakukan untuk mengurangi risiko penyebaran virus COVID19. Salah satunya adalah Pembatasan Sosial Berskala Besar (PSBB) yang dilakukan di beberapa kota besar di Indonesia. Kini Indonesia tengah menyambut kehidupan new 


\section{Jurnal ABDI MERCUSUAR}

normal, yaitu perubahan pola hidup di masa pandemi COVID-19. Virus COVID-19 umumnya ditularkan dari orang ke orang melalui droplet atau kontak langsung (misanya berjabat tangan atau cipika cipiki). Namun ada juga kemungkinan penularan melalui kontaminasi benda yang disentuh oleh pasien positif COVID-19. Hal ini yang mendasari pentingnya meningkatkan pola hidup bersih dan sehat. Berikut merupakan kiat kiat yang perlu dipahami untuk menyambut pola hidup pasca PSBB: Pastikan anda dalam kondisi sehat apabila berpergian ke luar rumah, Selalu gunakan masker, Selalu menjaga jarak dengan orang lain minimal satu meter, Saat memasuki tempat umum, seperti kantor, mall, dan restoran, usahakan untuk cuci tangan terlebih dahulu selama 20 detik dengan sabun dan air mengalir, upayakan menggunakan kendaraan pribadi, Upayakan membayar secara non tunai. Apabila menerima uang dari orang lain, segera gunakan handsanitizer sesudahnya. Selalu bersihkan meja kerja/meja makan dengan desinfektan, Gunakan siku untuk membuka pintu dan menekan tombol lift, Kurangi menyentuh wajah atau mengucek mata dengan tangan. Gunakan tissue bersih jika diperlukan, Saat tiba di rumah, usahakan segera mandi dan mencuci pakaian yang dipakai di luar. Jangan bersentuhan dengan anggota keluarga sebelum membersihkan diri. Jika dirasa perlu, bersihkan handphone, kacamata, tas, dengan desinfektan secara berkala (Kementerian Kesehatan Republik, 2020a).

Dari hasil kegiatan ini yang dilaksanakan dari pukul 07.00 sampai dengan 11.00 WIB. didapatkan 90\% dari 85 orang peserta antusias mendengar topik yang diberikan dimana topi saat ini adalah hidup sehat dalam masa Pandemi COVID-19, dimana dalam materi juga disampai cara mencuci tangan yang benar dan pola hidup yang sehat selama masa Pandemi seperi berolah raga minimal 2 kali seminggu dan makan makan yang sehat serta selalu menjaga imun, dan $45 \%$ peserta merespon dengan sangat baik dalam materi yang diberikan serta $60 \%$ peserta paham apa yang harus dilakukan untuk kedepan nya agar terhindar dari penyakit corona atau COVID-19 yang saat ini melonjak angka kejadian nya baik nasional maupun lokal.

Berdasarkan teori yang didapatkan atau pedoman pencegahan dan pengendalian oleh Kementerian Kesehatan Republik, 2020a, bahwa penularan COVID-19 yaitu dengan tetesan cairan (droplet) yang keluar saat berbicara, batuk atau bersin dan kontak pribadi seperti bersentuhan atau berjabat tangan. Selain itu penyebaran virus juga dapat terjadi saat menyentuh benda atau permukaan yang terkontaminasi virus kemudian menyentuh mulut, hidung, atau mata sebelum mencuci tangan. Bahkan virus Corona diperkirakan menyebar melalui kontak dekat dari orang ke orang meski pada Orang Tanpa Gejala (OTG).

Kasus yang paling banyak diinformasikan sebagai pemicu penyebaran infeksi virus SARS-CoV-2 adalah terjadinya kontak antar bagian tubuh manusia atau mereka yang pernah berinteraksi dengan seseorang yang telah terinfeksi dengan jarak sekitar satu meter. Ilmuan Cina telah menemukan jejak virus Corona pada tinja atau feses sejumlah pasien yang terinfeksi. Temuan itu bisa mengindikasikan cara penularan COVID-19. Padahal sebelumnya otoritas kesehatan mengira cara utama penyebaran virus ini adalah melalui transmisi dan kontak pernapasan, termasuk menyentuh wajah setelah 


\section{Jurnal ABDI MERCUSUAR}

menyentuh benda yang terinfeksi virus (Kementerian Kesehatan Republik, 2020b).

WHO dan melalui Kementerian Kesehatan memberikan arahan untuk melakukan beberapa langkah pencegahan agar dapat mengurangi risiko terinfeksi atau menyebarkan COVID-19. Diantaranya seringlah mencuci tangan dengan air bersih mengalir dan sabun, atau cairan antiseptik berbahan dasar alkohol dapat membunuh virus di tangan, jaga jarak setidaknya satu meter dengan orang yang batuk-batuk atau bersin-bersin, hindari menyentuh mata, hidung, dan mulut. Tangan menyentuh berbagai permukaan benda dan virus penyakit ini dapat tertempel di tangan. Tangan yang terkontaminasi dapat membawa virus ini ke mata, hidung atau mulut, yang dapat menjadi titik masuk virus ini ke tubuh sehingga seseorang menjadi sakit, tetaplah tinggal di rumah jika merasa kurang sehat, selalu memakai masker ketika terpaksa keluar rumah agar penularan virus COVID-19 bisa dicegah saat berpergian diluar rumah. (Kementerian Kesehatan Republik, 2020b).

\section{Kesimpulan dan Saran}

Tubuh sehat merupakan dambaan setiap orang, karena dengan tubuh yang sehat seseorang dapat melakukan aktivitas sehari-hari tanpa ada gangguan. Jika tubuh sehat, maka segala kegiatan hidup dapat terlaksana dengan baik. Pengertian hidup sehat dapat didefinisikan sebagai hidup tanpa ganguan masalah yang bersifat fisik maupun non fisik. Gangguan fisik berupa penyakit-penyakit yang menyerang tubuh. Sementara non fisik menyangkut kesehatan kondisi jiwa, hati dan pikiran seseorang. Artinya, kesehatan meliputi unsur jasmani dan rohani. Banyak orang yang secara jasmani memiliki tubuh yang sehat dan baik, namun kondisi rohani mereka sangat memprihatinkan. Ada berbagai macam untuk menjaga agar tubuh tetap sehat, salah satunya yaitu dengan merapkan PHBS serta menjaga sistem imun yaitu dengan menjaga kebugaran jasmani.

\section{Ucapan Terima Kasih}

Pelaksanaan kegiatan ini tidak lepas dari bantuan dan dukungan dari berbagai pihak. Pada kesempatan ini kami mengucapkan terima kasih kepada Yayasan dan STIKes MERCUBAKTIJAYA Padang, LPPM STIKes MERCUBAKTIJAYA Padang yang telah membantu dan memfasilitasi kegiatan pengabdian masyarakat ini.

\section{Daftar Referensi}

Budianto, Y. (2020). Memahami Karakter Virus dan Penyakit Covid-19. Kompas. https://bebas.kompas.id/baca/riset/2020/03/14/memahami-karakter-virus-danpenyakit-korona-covid-19/

Idah Wahidah, Muhammad Andi Septiadi, M. Choerul Adlie Rafqie, Nur Fitria, Salsabila Hartono, R. A. (2020). Pandemik Covid-19: Analisis Perencanaan Pemerintah dan Masyarakat dalam Berbagai Upaya Pencegahan. Jurnal Manajemen Dan Organisasi, 11(3), 179-188. https://doi.org/10.29244/jmo.v11i3.31695

Kementerian Kesehatan Republik, I. (2020a). Pedoman Pencegahan dan Pengendalian Coronavirus Disease (Covid-19) revisi ke-4. Direktorat Jenderal Pencegahan dan 


\section{Jurnal ABDI MERCUSUAR}

Vol. 01, No. 02, Desember, 2021, pp. 059 - 066

\section{Pengendalian Penyakit.}

Kementerian Kesehatan Republik, I. (2020b). Status Harian Covid-19 di Indonesia. https://covid19.kemkes.go.id/situasi-infeksi-emerging/info-corona-virus/

Luthviatin., et al. (2012). Dasar - Dasar Promosi Kesehatan dan Ilmu Perilaku. University Pass.

Pratiwi Eka, P. (2015). Perilaku Hidup Bersih dan Sehat (PHBS) Pada Tatanan Rumah Tangga Masyarakat Using. Fakultas Kesehatan Masyarakat.

UNICEF, W. and I. (2020). Key Messages and Actions for COVID-19 Prevention and Control In Schools. In UNICEF. https://www.unicef.org/indonesia/id/laporan/panduan-sekolah-untukpencegahan-coronavirus 